\title{
The Principle of Common Good in Ibuanyidanda Philosophy and Egocentrism in Nigeria's Political Leadership
}

\author{
Onyemachi Felix Chukwudi \\ University of Calabar, Calabar, Cross River State Nigeria. \\ Email: onyemachifelix@gmail.com
}

(Received: May-2020; Reviewed: July-2020; Accepted: July-2020;

Avalaible Online: July-2020; Published: August-2020)

This is an open access article distributed under the Creative Commons Attribution License

CC-BY-NC-4.0 C2020 by author (https://creativecommons.org/licenses/by-nc/4.0/)

\begin{abstract}
The paper aims at resolving the issue of egocentrism using the principle of common good in Ibuanyidanda Philosophy within the context of Nigeria's political leadership. The paper makes analyses of the concepts of egocentrism, leadership, common Good and Ibuanyidanda Philosophy. The paper examines egocentrism in Nigeria's political leadership, and identifies it as a menace which among other ravages, has consequences of economic, social and moral decline in the nation. The paper argues that Nigeria would have known growth and development in all spheres of her existence if the leaders had conscientiously given comprehensive and selfless services in their leadership mandates. The paper, therefore, concludes that Nigeria will only experience all-round development and attain an enviable height in the comity of nations when the Principle of Common Good in Ibuanyidanda Philosophy which promotes inclusiveness, committedness and selflessness as against self-centredness, exclusiveness and 'we-them' mentality is adopted by policy makers, and ingrained in Nigeria's political leadership.
\end{abstract}

Keywords: Egocentrism; Political Leadership; Common Good; Ibuanyidanda Philosophy

\section{INTRODUCTION}

Leadership has been a serious issue that plagues the Nigerian nation for many years with serious consequences. The desire of Nigerians to have a good and inclusive political and economic stability had not been actualized by our political leaders since independence in 1960. It is regrettable that although election manifestos and statements of political parties and leaders respectively seem to be people oriented, actions of these political leaders prove otherwise (Makinde 2004, p. 222). Unfortunately, what works in other nations within and outside Africa has not been working for Nigerians because successive leaders over the years have been dishonest and promoting their own interest over the general interest of the nation.

Philemon Amanzee (2004) confirms the scenario in his observation that in Nigeria much of the contemporary debate about leadership stems from the fact that most of the people who have been entrusted with the sacred responsibility of leadership have woefully failed (p. 75). The problem of leadership in Nigeria's political space has not only affected and truncated the 
national development, but, also, shown that the quality of leadership in the nation is a far cry from what is expected. It was in this connection that Chinua Achebe (1983) made the point that "the trouble with Nigeria is simply and squarely the failure of leadership" (p. 1).

As a result of a misplacement of priority and the ambivalence of human mind, Nigeria has suffered setbacks and unproductivity in both the military and civilian systems of government. Due to the natural inclination to self-preservation, the human mind tends to be exclusive and divisive as it seeks to acquire all good things for itself and for itself alone. It is for this reason according to Innocent Asouzu (2004), that one perceives one's interest as fundamentally good, even when they have lost credibility (p. 60).

Accordingly, the ambivalent human mind has occasioned a situation where those at the helm of affairs in different strata of the society seek to uphold their own interest or the interest of those closely related to them either by ethnicity or zone, while paying less attention to national interest. Expectedly, the individuals, groups and others who feel sidelined, segregated or discriminated against are agitating as the natural and national resources meant for the common good are enjoyed only by the leaders and their cronies. To this end, Nigeria's political leadership has been challenged as the common good is sacrificed at the altar of absolute possessiveness and exclusiveness.

It is against this egoistic trend of leadership which has marred the effectiveness of Nigeria's leadership, as well as questioned the credibility of Nigerian leaders that this paper seeks to use the principle of common good as articulated in Ibuanyidanda Philosophy which is against all forms of selfishness, exclusiveness and 'we-them' mindset, with a view to reengineering Nigeria's political leadership mentality. This is done in the hope that this viable postulation would promote all inclusive, harmonizing and comprehensive aspects of Nigerians life.

\section{Analysis of Concepts: Egocentrism}

Egocentrism simply means self-centredness. According to online dictionary, it means "having or regarding the self or the individual as the center of all things" (https://www.dictionary.com). This would mean having no regard for others' interests other than one's own interest. This aligns with Asouzu's (2003) description of it as "the disposition always in all situations to desire undue advantage for and solely for the person or persons involved in total disregard of the common good" (p. 20). This implies a sense of exclusiveness, selfishness and wanton disregard for the good of others. Hence, in the act of egocentrism (self-centredness) one places himself/herself always above those regarded as 'others' while regarding his interest as supreme. Conversely, one is not selfish when one seeks his/her interest within the ambience of the common good, but, when one's interest takes pre-eminence over the good of all with whom one has a common goal, there sets in self-centredness which is in contrast with the essence of existence.

\section{Leadership}

Leadership according to Sylvanus Iwe (1978) is a natural and inevitable attributes of a society. For a society to be without leadership is like a body without a head (p. 15). He argues that a society without a good leadership is bound to be in disarray. Andrew Uduigwomen (1997) corroborated the above when he made the point that "Group life is a practical impossibility 
without a responsible leadership. Leadership is what the head and the eye are to a human person.... Leadership is an indispensable element of social organization. A nation is therefore what the leaders have made it" (p. 61). Implicit in the above are inherent qualities needed in leadership. Among the qualities according to Uduigwomen is the ability to generate cooperation and stimulate initiative (p. 61). Plato (1955) on his part differs a bit as he earmarked wisdom as the only quality that distinguishes a good leader, hence, his idea of the philosopher king. According to him, "Unless philosophers are kings and princess of the world have the spirit and power of philosophy and political greatness and wisdom meet in one, and these numerous natures who pursue either to the exclusion of the other are forcibly restrained from doing so, cities will never rest from their evils, nor the human race" (p. 280). Following Plato's position, one can infer that wisdom for Plato ranks highest among all leadership qualities; and that is why he maintains that for a society to make progress, leaders must embrace wisdom.

Enumerating the qualities of leadership further, Godfrey Ozumba (2005) avers that, "A leader must have clear vision, have the will power and courage to carry others along for the actualization of his vision which must be for the overall good of the people his is leading" ( $p$. 106). One can deduce from the above qualities, an approach a leader must adopt by carrying everybody along in the realization of the society's set goals or agenda. Appositely, Soludo confirmed this as an ideal mechanism which according to him is the ability to bring people together to dedicate themselves to the pursuit of a common goal. It is on this basis that Asouzu describes leadership as "the unification of all human interests towards the determination of the destiny of the whole man" (p. 67). Therefore, a society realizes its set goals and objectives when all human and material resources are complementarily harnessed and enjoyed by all with no differentiating characteristics.

\section{Ibuanyidanda Philosophy}

This philosophical though system known as Ibuanyidanda, is founded by Innocent Asouzu. Ibuanyidanda is derived from three Igbo words: 'Ibu' which means 'load' or 'task', 'anyi' which means "not insurmountable for", and 'danda' which means 'a species of ants'. Therefore, Ibuanyidanda would mean "no load in insurmountable for danda the ants" (Ibuanyidanda, 2007, p. 11). Ibuanyidanda connotes to the Igbo, the worth of mutual dependence and interdependence in complementarity of all. For the traditional Igbo philosophers, "for anything to claim existence, it has to fulfill a minimum condition which subsists in its commitment to a mutual complementary relationship between it and the other units with which it shares a common framework" (pp. 11-12).

Ibuanyidanda Philosophy is contrived considering the founder's knowledge of authentic African traditions in the Igbo community. As the African traditional worldview shows to a reasonable extent, "strong moments of the transcendent ontological categories of unity, totality, universality, comprehensiveness, wholeness and future referentiality as authentic dimensions of thorough-going complementarity" (Ibuaru, 2007, p. 10). This philosophy sees reality as allembracing; where the missing links exist in complementarity. In this philosophy, the concept of 'being' is seen as "that on a account of which anything that exists serves a missing link of reality" (10). Therefore, a thing can be affirmed to exist if and only if it is grasped within the framework of complementary relationship of all existent realities. Ibuanyidanda Philosophy, therefore, aimed at defusing class consciousness, ethnocentric commitment and self-centredness that exist in the world. 


\section{Common Good}

According to the Stanford Encyclopedia of Philosophy, "Common good refers to those facilities whether material, cultural or institutional, that the members in order to fulfill a relational obligation they all have to care for certain interests that they have in common" (https://plato.stanford.edu). The facilities as deduced from the above will include: the road system, public schools, courts and the judicial system, public parks, police protection and public safety, museums and cultural institutions, pipe-borne water, and so on. The above definition is not in contrast with John Thornhill's (1967), who sees common good as a benefit which human persons can only attain through the coordination of their activities (p. 45). But, Jacques Maritain (1966) differs as he gives a relational dimension of the concept of common good. For him, "it is the good human life of the multitude, of a multitude of persons; it is their communion in good living" (p. 437). In this sense, common good in itself includes the life of persons and liberty of expansion with its consequent communications of generosity.

Appositely, Asouzu (2003) gives a more holistic description of common good. For him, common good can be understood in two senses. First, common good refers to the "ultimate authenticating anthropological basic constant of human life. It is that ultimate common foundation that gives legitimacy to all human actions" (p. 380). Here, common good has a character of complementary imperative and a fundamental relational dimension. In a relational or reciprocal relationship, all units are necessarily bound complementarily. This relationship is by necessity characterized by give and take in complementary mutual dependence and bonding. In the second sense, common good refers to authenticating foundation of interpersonal relationship in society, which is expressed in those social and empirical goods and services we own in common whose upkeep is of necessity for well-coordinated and contented existence (p. 380). In this sense, common good includes the natural and material resources and facilities we own in common by virtue of their communal use and utility.

Therefore, common good in Ibuanyidanda Philosophy would be understood not only from the goods and services or facilities we own and share in common, but, also, from the relational dimension of human existence. With its distinguishing features of common possession, mutual relationship and inclusiveness, common good in Ibuanyidanda Philosophy, advances the harmonization of individual's interest with the interests of others.

\section{Egocentrism: A Cog in the Wheel of Nigeria's Political Leadership}

Gabriel Ncha (2018) was categorical when he said that, "In Nigeria, both economic, political, social, ethnic and religious problems are attributed to the way and manner leadership manages the affairs of the nation" (p. 343). The Nigerian society today is a mere theatre for the pursuit of selfish ends, a place engulfed in bitter struggle for who gets what for one's self, one's friends, and family (J.Eneh \& C.B. Okolo, 1998, p. 48). Egocentrism (selfcentredness/selfishness) is one among other evils that bedevils the nation's political leadership. Elijah Abiodun Obayelu (2010) could be correct to describe it as "efforts to secure wealth... for private gain at public expense, or a misuse of public power for private benefits" (p. 237), when one considers how Nigeria's political leaders only care for the good of self or those close to them with little or no consideration to the poor masses. As such, this has hampered Nigeria's leadership development and progress. 
Nigeria appears to be a nation where no one coming to power is without ulterior motives of selfish end. The spirit of "I alonism" has taken a high seat on the minds of the leaders. No one is taken up political responsibilities in Nigeria to serve the masses, but, rather, to amass wealth for himself/herself and his cronies. Unfortunately, as Chris Agule (2006) Observes, "the tendency to amass wealth through the 'I' and 'me' syndrome had killed the conscience of many Nigerians, as they involve in all forms of cheating" (p. 82). Substantiating the above observation, Titus Mamadu (2009) made the point that, "For most Nigerians, the reason for contesting for any political post is not to serve the mother land, but rather an avenue to acquire wealth and riches at the detriment of the poor masses" (p. 75). The citizens, especially the poor masses that should enjoy the national dividends are neglected and relegated to the background as national wealth is pocketed by those in positions of leadership. It is in this light that, Victor Anya (2012), decries: "The way and manner Nigeria is being governed since independence in 1960 shows that elected politicians and public office holders pursue self-interest rather than national interest" (https"//www.dailyindpendencenig.com). It is a truism that no country progresses whose leaders pursue selfish interest rather than the common good. A nation whose leaders divert money budgeted for the national well-being to their private pockets is bound to remain unprogressive; and no institutions work in that condition because the common good has been shortchanged.

It is a regrettable scenario as this menace of egocentrism is so glaring in the ways Nigerian leaders award contracts and other official assignments that involve monetary project. They tend to selfishly award contracts to their relatives, friends and cronies even when the people do not have the prerequisites for such; and in the face of this, nothing works well. Simon Kolawole (2015) corroborated this claim when he made the point that: "Nigeria would have been a better place today. Our rulers have been busy feathering their nests and the nests of their cronies over the years. The money that should have gone into developing infrastructure to facilitate economic growth and development has been going into private pockets"(https://www.thisdaylive.com). Which country would be in this leadership mess and expect the nation to experience growth or development? Almost on daily basis, Nigeria's political leaders which include, ex-presidents, ex-governors, Senators, past Local Government Chairmen and others with leadership portfolios are invited either by the Economic and Financial Crimes Commission (EFFC) or Independent Corrupt Practices and other related Offences Commission (ICPC) for questioning and explanation on their financial recklessness at the expense of their consistencies. Given the display of financial recklessness of our political leaders in Federal, State and Local levels, one would be forced to suggest that Nigeria be better ruled by the Military. But the Military is not far from being selfish as there have been cases of looted funds by past Military Heads of State. Take for instance, the stolen money stashed in other countries by the then President, General Sani Abacha out of selfishness at the expense of the masses has been under serious investigations as some recoveries have been made. The recovered monies by successive governments according to Livinus Nwabughiogu (2020), were stashed away in four major countries, to include Switzerland, Jersey Island in United Kingdom, United States and Liechtenstein. To substantiate his claim, he revealed that: "During the Abdulsalami era in 1999, $\$ 750$ million was recovered. Under the Obasanjo administration, $\$ 1.2$ billion was recovered in 2002; \$149 million from Jersey Island, Uk in 2003, \$500 Million recovered in 2004 from Switzerland and another \$458 recovered in 2005 from Switzerland. During the Jonathan administration, \$1 billion was recovered in 2012 and \$ 380 million in 2015, both tranches from Switzerland. The Jonathan administration also recovered \$227 million from 
Liechtenstein in 2014 and \$48 million from the United States the same year. The government of Buhari recovered \$322 million from Switzerland in 2017 and \$308 million from Jersey Island, United Kingdom in February 2020 which is the most current" (https://www.vanguardngr.com). This is an abomination if the claim of Asouzu (2003) is true that, "a person who sacrifices the common good at the altar of his private interest automatically falls within the bracket of abominable crimes in the eyes of the Igbo" (p. 63). Though a particular military head of state is used to buttress the claim of selfish interest among the Military, other set of self-centred military rulers abound as some are facing court charges, imprisoned, while others are yet to be identified. What a shame.

Obviously, Karl Maier as cited by Mamadu (2009) was right when he said that: "Nigerians spend a good part of their lives trying to get the better of the government for their own benefit or that of their family, the village or their region. Rare is the head of state who acts on behalf of the entire nation" (p. 76). So disappointing that Nigeria's leaders are only interested in bettering their families, friends, village, communities and those close them. In a situation like that, how would the nation have a healthy and all-round development since the resources meant for all are enjoyed by few persons? The national and natural resources which should be used and utilized for the nation's common good are rather used for the leaders' personal and selfish desires. The country that is blessed with natural resources of many kinds, are dragging their feet in the comity of nations. It is in this light that Emmanuel Ejere (2012) made the point that, "Nigerians are suffering in the midst of plenty. Nothing typifies bad governance more than the fact that despite being the sixth crude oil exporter in the world, Nigeria is a net importer of refined petroleum products; and her government expects her citizens to pay international price for petroleum products. Generally, top government officials ride rough shod over the people and care little about their welfare. They indulge in sheer conspicuous public consumption at the expense of their poverty stricken people" (p. 957). This is a clear indication that Nigeria's leaders are more interested in their welfare than the masses under their leadership. Morality or societal values of honesty, patriotism, trustworthiness and selflessness are far from being found among the leaders. And that is why Nigerian politicians would go to any length to acquire power, and would always try to retain the power because of their egocentric desires.

From the foregoing, one can deduce that greed and selfish interest over collective interest of the nation have marred rather than make the nation because individual leaders' interests are at variance with the collective interest of the nation. It is against this backdrop that Chris Agule (2006) contends that, "Until we discard this self-centred tendency and see beyond ourselves the situation will remain unchanged" (p. 82). To discard this ugly element that has eroded the dignity and integrity of the giant of Africa, calls for a re-engineering of Nigeria's political leadership mentality.

\section{The Principle of Common Good in Ibuanyidanda Philosophy: A Panacea}

No doubt, naturally, human beings have the urge to perceive the tendency to selfpreservation and the pursuit of interest as that which is good in itself, the principle of common good as articulated in Ibuanyidanda Philosophy is of the view that often times, not all our interests are good the way we perceive them. Again, the way we perceive our interests as individuals as well as groups goes a long way in determining the way we act towards these interests. And according to Asouzu (2003), "Our ability to understand this relation between personal interest and common good, positions us well to be true citizens who can say that they 
love their country and all the institutions and peoples of which it is constituted" (p. 93). So disheartening a fact, that selfish interest has taken the front seat in Nigeria's leadership, so much so that those at the helm of affairs only think about themselves and those related to them with little or no attention to the people that gave them mandate; and this without doubt, has done more harm than good in Nigeria in many aspects of her national existence. For instance, socially, it has brought about dichotomization between the people in leadership and the masses in their relationships; hence, the idea of the first class citizens and the second class citizens. It is in this respect that Dorothy Ucheaga (2009) warned that "no one or group should be seen as a second class citizen" (p. 144). Economically, it has equally created a gap between the rich and the poor. This is made evident in the type of food the citizens of the same nation consume. The political elites, leaders, and their family members would go for quality while the poor masses will go for quantity; hence, the cases of malnourishment and sicknesses of all kinds among the poor; also leading to cases of societal ills such as armed robbery, prostitution, kidnapping and the likes, in an effort to earn a living by the poor victims. Morally, not only that Nigeria and her leadership are poorly evaluated given their selfish leadership approach in the comity of nations, it equally, as identified in its economic implication, inextricably exposed the poor masses to immoral adventures and dealings to earn a living which contributed to the moral decadence prevalent in Nigeria. Today in Nigeria, if it is not money ritual, kidnapping, armed robbery, child trafficking, it will be prostitution; all because the resources these victims would have enjoyed in the nation, are selfishly cornered by those in the positions of authority. Egocentrism, therefore, has become a worrisome phenomenon in Nigeria's political leadership to the consternation of the citizenry. It is in this connection that this paper brings one of the principle's distinguishing features of common possession to bear on the Nigerian situation.

Common possession as an ingredient of the principle of common good in Ibuanyidanda Philosophy in this sense, is the common right which enjoins every citizen within a geographical area to enjoy the national resources to the fullest. These resources include basic facilities, institutions, natural resources which are supposedly to be shared in common by all irrespective of gender, class or family background. This implies that any exclusive claim as selfish political leaders would portray to these resources is tantamount to alienation against the excluded masses. Common possession, ideally, makes provision for the needs of all (the leader and the led); hence the national resources ought to be used by all the citizens by virtue of their economic standing to meet the basic needs of life such as food, health facilities, education, good water, electricity, good road network and so on. But unfortunately, these necessities of life appeared to be enjoyed only by the political leaders and elites while the poor masses are wallowing in abject poverty.

Regrettably, today, Nigeria that is blessed with oil and other natural resources has nothing to show for it when one considers how the nation is filled with beggars. Cases of armed robbery, kidnapping, prostitution and the likes, abound because of unemployment and poor livelihood. The money meant to cater for the less privileged and internally displaced persons are cornered by the leaders just for personal gain. Nigerian citizens sit on abundance, but live in poverty. The roads that should have been built to a standard, given the gains the nation makes from the natural resources which nature has given her, are begging for national attention. What an irony.

What resonates, following the foregoing is unbridled agitations by the neglected and disregarded poor masses. For if the political leaders would utilize the national resources to provide food for the citizens, create industries, build good roads, provide health and educational facilities and other necessities of life, the poor masses would not regret reposing the trust in 
their political leaders. Hence, the principle of common good as articulated in Ibuanyidanda Philosophy which advocates the need for common possession in the Nigerian state advances the use of national and natural resources and what accrues from them not for the leaders' selfish end, but, to meet the basic human needs of every Nigerian irrespective of class, gender, ethnicity or any social affiliation; because, according to Asouzu (2004), "we own these resources collectively and they can help us add more quality and meaning to our individual existence. As common goods, we are challenged to uphold and preserve them as a common legacy. If we are successful, they can be a cause of our joy and in this case, we sense the urge within us, which challenges us to keep them as something good, to hold firmly to them now and in all future cases. This challenge is possible primarily as a mutual experience" (p. 381). It is no doubt that, when leaders eschew self-centredness in their leadership, the Nigerian state would be rebranded and known as a 'nation of integrity' in the comity of nations. This will equally go a long way to not only ameliorating Nigerians livelihood, but, also, reduce societal ills while engendering meaningful and harmonious existence in the country. Hence, by virtue of the common possession, each individual needs this common wealth to be sustained in the nation; and nobody, including the leaders is expected to have exclusive claim to this wealth beyond what is due to him or her.

\section{CONCLUSION}

This paper set out to resolve the issue of egocentrism in Nigeria's political leadership. The paper identify among other ravages of egocentrism in the Nigerian state, the economic, social and moral decline. The paper was quick to point out that egocentrism in Nigeria's political leadership is a $\operatorname{cog}$ in the wheel of the nation's development in all spheres of her existence. Further, the Ibuanyidanda Philosophical principle of Common Good needed as a principle of action to overturn egocentric leadership mindset was exposed.

In view of the above, the paper concluded that Nigeria will only experience all-round development in the nation when the Principle of Common Good in Ibuanyidanda Philosophy which promotes selflessness, inclusiveness and committedness as against selfishness, exclusiveness and 'we-them' mentality is adopted by policy makers, and ingrained in Nigeria's political leadership.

\section{REFERENCES}

Achebe, C. (1983). The Trouble with Nigeria. Enugu: Forth Dimension.

Agule, C. (2006). Social Injustice: The Challenge of Religion in Nigeria. Makurdi: Treaces.

Amanzee, P. O. (2004). "An Appraisal of the Ministry of Moses and its implications for Religious Leaders Today". Religion, Leadership and Society: Focus on Nigeria. Eds. Dopamu A.P. et al. Lagos: Free Enterprise Publishers, 318-325.

Anya, V. (2012). "Between National and Self Interest". Daily Independence. Https://www.dailyindependence.com. 14 January. Retrieved 10-6-2020.

Asouzu, I. (2004). The Method and Principles of Contemporary Reflection in and beyond African Philosophy. Calabar: University of Calabar Press. 
Asouzu, I. (2003). Effective Leadership and the Ambivalence of Human Interest: The Nigerian Paradox in a Complementary Perspective. Calabar: University of Calabar Press.

Asouzu, I. (2007). Ibuaru: The Heavy Burden of Philosophy Beyond African Philosophy. Zweigniederlassung Zurich: Litverlag GmbH \& Co. KG Wein.

Asouzu, I. (2007). Ibuanyidanda: New Complementary Ontolopy Beyond World-immanentism, Ethnocentric Reduction and Impositions. Zweigniederlassung Zurich: Litverlag GmbH \& Co. KG Wein.

Ejere, E. (2012). "Promoting Accountability in Public Sector Management in Today's Democratic Nigerian". Book of Proceedings-Tourism and Management Studies International Conference. Vol.3, 953-964.

Https://www.dictionary.com/browse/egocentrism. Retrieved 10-6-2020.

Iwe, S. (1978). Ethics and Society. Lagos: Sevitin Publihers.

Eneh, J. O. and Okolo, C. B. (1998). "The Common Good and Political Stability". Philosophy and Politics Discourse on Values and Power in Africa. Ed. Dukor Maduabuchi. Lagos: Obaroh \& Ogbinaka Publishers Limited, (pp. 47-56).

Kolawole, S. (2015). "Nigeria: Problems and Solutions". This Day Live. Https://www.thisdaylive.com. 2 October. Retrieved 10-6-2020.

Maintain, J. (1966). The Person and the Common Good. Indiana: University of Nostre Dame Press.

Makinde, A. (2004). "Political Leadership Problem in Nigeria: A Panacea from Islamic Perspective". Religion, Leadership and Society: Focus on Nigeria. Eds. Dopamu A.P. et al. Lagos: Free Enterprise Publishers, (pp. 220-225).

Mamadu, T. (2009). Corruption in the Leadership Structure of Nigerian Polity. Calabar: Jochrisam Publishers.

Ncha, G. (2018). "Existential Justice: The Basis for Quality Leadership in Nigeria". Calabar Journal of Liberal Studies: An Interdisciplinary Journal. 20 (2), 337-347.

Nwabughiogu, L. (2020). "Abacha Loot: How Much did the late Head of State steal?" Vanguard. Https://www.vanguard.com/2020/03/abacha-loot-how-much-did-the-head-ofstate-steal. 8 March. Retrieved 12-6-2020.

Obayelu, A. E. (2010). "Effects of Corruption and Economic Reforms in Economic Growth and Development Lesson from Nigeria". Journal of Social Sciences. 2 (4), 233-241.

Ozumba, G. (2005). "Restructuring the Nigerian Leadership through Phiosophical Enterprise". Sophia: An African Journal of Philosophy, 7(2), 106-113.

Plato. (1955). The Republic. Harmondiworth: Penguins.

Stanford Encyclopedia of Philosophy. (2018). Https://plato.standford.edu/index.html. 26 February. Retrieved 10-6-2020.

Thornhill, J. S. M. (1967). The Person and the Group. Milwankee: The Bruce Publishing Company. 
Volume 3, Issue 2, March, 2020 Page. 93- 102

Ucheaga, D. (2009). "Sustainable Development and the Ethnic Minority Question in Nigeria". ABIBISEM: Journal of African Culture and Civilization. Vol. 2. 107-124.

Uduigwomen, A. (1997). "Leadership and Nigeria's Socio-Political Malaise". Nigeria: Government and Politics. Ed. Ozumba Godfrey. Aba: AAU Industries. 